\title{
Plasma Angiotensins, Renin, and Blood Pressure During Acute Renin Inhibition by CGP 38 560A in Hypertensive Patients
}

Xavier Jeunemaître, Joël Ménard, Jurg Nussberger, Tam T. Guyene, Hans R. Brunner, and Pierre Corvol

The new renin inhibitor CGP $38560 A$ has been shown to block angiotensin (ANG) production in healthy volunteers. In order to determine its potential antihypertensive effect, the compound was administered in a 30-min infusion, in 12 hypertensive patients (mean blood pressure (BP): $112.8 \pm 3.5 \mathrm{~mm} \mathrm{Hg}$ ). These patients were selected for their sensitivity to captopril: a single oral dose of $50 \mathrm{mg}$ captopril lowered their mean BP by $8.8 \pm 2.2 \mathrm{~mm} \mathrm{Hg}$ after $30 \mathrm{~min}$ and by $15.3 \pm$ $1.5 \mathrm{~mm} \mathrm{Hg}$ after $90 \mathrm{~min}$. At the end of the renin inhibitor infusion, mean blood pressure decreased by $5.7 \pm 2.2 \mathrm{~mm} \mathrm{Hg}$ in the six patients infused with the dose of $0.125 \mathrm{mg} / \mathrm{kg}$ and by $6.0 \pm 1.8 \mathrm{~mm} \mathrm{Hg}$ in the six patients infused with $0.250 \mathrm{mg} / \mathrm{kg}$. The fall in blood pressure was correlated to the initial plasma renin activity (PRA) $(\mathrm{r}=0.61, P<.05)$. A dose-dependent effect was observed on plasma ANG I which fell by $74 \%$ with $0.125 \mathrm{mg} / \mathrm{kg}$ and by $94 \%$ with $0.250 \mathrm{mg} / \mathrm{kg}$. Identical falls were found for plasma ANG II (72\% and 94\%, respectively) and ANG I and ANG II were well correlated $(r=0.91$, $P<.001)$. The fall in BP was correlated to the fall in plasma ANG I (r $=0.77, P<.01)$. The time-course of the BP changes was parallel to the changes in plasma angiotensins, as were the slightly delayed rise and fall in active renin measured by a direct immunoradiometric assay. When measured by the conventional ANG I radioimmunoassay, PRA values indicated a long-lasting inhibition. The artefactual nature of the latter result is demonstrated by the different results obtained with an ANG I antibody-trapping radioimmunoassay, which followed more closely plasma ANG I levels. Am J Hypertens 1989; 2:819-827

KEY WORDS: Renin inhibition, plasma renin activity, plasma angiotensins, blood pressure, converting enzyme inhibition, active renin.

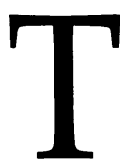
he goal of research on renin inhibition is to achieve a more specific blockade of the reninangiotensin system (RAS) than is possible with angiotensin converting enzyme (ACE) inhibition. Indeed, renin is an enzyme which acts on a unique substrate, angiotensinogen, whereas converting enzyme splits several substrates, including bradykinin,

From INSERM U36, Paris, France (XJ, TTG, PC) Ciba-Geigy, Basle, Switzerland, (JM) and CHUV, Lausanne, Switzerland (JN, HRB).

Address correspondence and reprint requests to Professor Joël Ménard, International Clinical Research \& Development, Ciba-Geigy Limited, $\mathrm{CH}-4022$ Basle, Switzerland. which may enhance the efficacy of this therapeutic approach to hypertension and congestive heart failure, and may also cause some of its side-effects. ${ }^{1}$ It is also expected that the clinical use of renin inhibitors will provide a better tool than ACE inhibitors for investigating the contribution of the RAS to the regulation of blood pressure and general hemodynamics. The angiotensin II (ANG II) antagonist, saralasin, and the ACE inhibitor, teprotide, were the first pharmacological tools used for this purpose. Depending on the prevailing plasma renin activity (PRA), their hypotensive effects were substantially different. ${ }^{2}$ They both lowered blood pressure more when the prevailing PRA was high; over- 
all, teprotide was more effective. The superiority of the ACE inhibitor over the ANG II antagonist was explained by the partially agonistic properties of saralasin, and possibly by the additional effects of the ACE inhibitor on several vasoactive mechanisms outside of the RAS. Renin inhibitors should help in evaluating more specifically the renin contribution to hypertension, but they may also have their own limitations, as already suggested by animal experiments. ${ }^{3,4}$

The present study was designed to study the efficacy and potency of the recently synthesized renin inhibitor CGP $38560 \mathrm{~A}$ in hypertensive patients who responded favorably to captopril. CGP $38560 \mathrm{~A}$ is a potent, lowmolecular-weight, human renin inhibitor, ${ }^{5}$ which has been shown to decrease blood pressure of marmosets, and to be well tolerated by normal volunteers maintained on a normal sodium $\operatorname{diet}^{6}$ or after mild sodium depletion. ${ }^{7}$

\section{METHODS}

Patients Twelve hypertensive patients whose blood pressures ranged from $166 / 108$ to $190 / 130 \mathrm{~mm} \mathrm{Hg}$ at their first visit to the Hypertension Clinic were studied. All were hospitalized. They had been selected according to the effects on blood pressure of a single oral administration of captopril. ${ }^{8}$

This captopril test was performed at 8:00 AM, after $60 \mathrm{~min}$ rest in the supine position, 1 to 4 days before the renin-inhibitor infusion. The patients received a single oral dose of $50 \mathrm{mg}$ of captopril. Their mean arterial blood pressure (MABP) was monitored every 5 min by an automatic device (oscillometric method, Sentron) and was analyzed between $30 \mathrm{~min}$ before and $90 \mathrm{~min}$ after administration of captopril. The patients were selected for CGP 38 560A infusion if their MABP before captopril was $110 \mathrm{~mm} \mathrm{Hg}$ and if higher or their blood pressure fell by $10 \mathrm{~mm} \mathrm{Hg}$ or more between 60 and $90 \mathrm{~min}$ after captopril intake. A blood sample for renin and aldosterone measurements was drawn before and $90 \mathrm{~min}$ after the captopril administration.

Of the 12 patients included in our study, all but one were Caucasians. Their mean age was $38 \pm 12$ years. They had no renal or hepatic insufficiency, no proteinuria and no previous history of cardiovascular disease. Five of them had a unilateral renal artery stenosis, two a unilateral segmental renal hypoplasia and five essential hypertension. Bilateral kidney disease, primary aldosteronism and pheochromocytoma were excluded by the usual tests.

Study Protocol All patients were maintained on a daily sodium intake of $100 \mathrm{mmol}$ daily for at least 3 days prior to the study. The study protocol was approved by the Broussais Hospital Ethics Committee, and all patients gave their informed consent, in writing. All drugs, including antihypertensive agents, were withdrawn at least one week prior to the start of the study, except for one patient who received nifedipine until $24 \mathrm{~h}$ before the captopril test.

Patients were recumbent when a catheter was inserted in the antecubital vein at 8:00 $\mathrm{Am}$. Blood pressure was monitored every $5 \mathrm{~min}$ for $20 \mathrm{~min}$, and then at 2-min intervals for $10 \mathrm{~min}$ prior to the start of the 30min intravenous infusion of the renin inhibitor, CGP 38 $560 \mathrm{~A}$ (time 0 ). The measurements at 2-min intervals were maintained for another $30 \mathrm{~min}$ and then blood pressure was measured at 5 -min intervals for $90 \mathrm{~min}$. CGP 38 560A was infused via the catheter and blood samples were drawn from a venous catheter inserted in the other arm. CGP $38560 \mathrm{~A}$ was infused at a constant rate over $30 \mathrm{~min}$, the total dose being diluted in $125 \mathrm{ml}$ isotonic $5 \%$ glucose.

Six patients (average age: $39 \pm 16$ years; average MABP: $110 \pm 11 \mathrm{~mm} \mathrm{Hg}$ ) each received a cumulative dose of $0.125 \mathrm{mg} / \mathrm{kg}$ and the other six of cumulative dose of $0.250 \mathrm{mg} / \mathrm{kg}$ (average age: $38 \pm 6$ years; average MABP $115.5 \pm 13 \mathrm{~mm} \mathrm{Hg}$ ). A second captopril test was performed the day after the infusion of the renin inhibitor in 4 patients who had received $0.125 \mathrm{mg} / \mathrm{kg}$ of the renin inhibitor and in 3 patients who had received $0.250 \mathrm{mg} / \mathrm{kg}$. The purpose of the second test was to eliminate the order effect in the comparison between the effects of captopril and the renin inhibitor on blood pressure.

Assays The methods of plasma renin measurement are shown in Table 1. Plasma renin activity (PRA) was measured by a ANG I radioimmunoassay: the in vitro rate of angiotensin I (ANG I) generation during incubation of

\section{TABLE 1. METHODS OF PLASMA RENIN MEASUREMENT}

\section{Plasma Renin Activity (PRA)}

This conventional method measures, by radioimmunoassay, the ANG I generated in plasma during a defined incubation. During the incubation, degradation of generated ANG I is prevented by chemical inhibitors added to the plasma prior to the incubation. ${ }^{9}$

\section{Plasma Renin Activity (PRT-TA)}

This method measures, by radioimmunoassay, the ANG I generated in plasma during a defined incubation. During the incubation, degradation of generated ANG I is prevented by the anti-ANG I antibodies used in the subsequent radioimmunoassay, which are added to the plasma in a high concentration, prior to the incubation, and which trap ANG I. ${ }^{10}$

\section{Plasma Active Renin}

(immunoradiometric assay - IRMA) (AR)

This method measures the concentration of active renin molecules in plasma, in a sandwhich assay using two monoclonal antibodies. The first antibody traps active and inactive renins and the second - iodinated-antibody binds to an epitope specific for active renin. This measurement is independent of the enzymatic activity of renin. ${ }^{11}$ 
endogenous renin and angiotensinogen in plasma at $\mathrm{pH} \mathrm{5.7}$, at $37^{\circ} \mathrm{C}$, for $90 \mathrm{~min}$, was determined by the method of Sealey et al. ${ }^{19}$ It was also evaluated by an enzymatic/ANG I trapping assay (PRA-TA) according to Poulsen and Jorgensen. ${ }^{10}$ Active immunoreactive renin (AR) was measured by an immunoradiometric assay according to Ménard et al. ${ }^{11}$ The monoclonal antibody used to detect active renin specifically recognizes an epitope of active renin and does not cross-react with inactive renin which is devoid of this recognition site. In all 12 patients, before and after captopril ingestion and before the renin inhibitor infusion, all measurements of renin were closely correlated (PRA $v$ PRA-TA: $\mathrm{r}=0.78$, $\mathrm{n}=12, P<.01 ;$ PRA $v$ AR: $\mathrm{r}=0.935, \mathrm{n}=36, P<.001$; PRA-TA $v$ AR: $\mathrm{r}=0.68, \mathrm{n}=12, P=.01$ ). Aldosterone was measured after extraction from plasma by the method of Pham and Corvol. ${ }^{12}$

For the measurements of plasma ANG I and ANG II, CGP $38560 \mathrm{~A}$ was added to all tubes, according to Nussberger et al. ${ }^{13}$ Plasma ANG I was measured after immediate centrifugation of blood and extraction of plasma on a phenylsilica column (Bondelut PH). A very sensitive assay was set up for ANG I which is able to detect $0.5 \mathrm{fmol} / \mathrm{mL}^{-1}$. The $50 \%$ displacement of the iodinated tracer in the standard curve is obtained with 7 $\mathrm{fmol} /$ tube of ANG I. For plasma ANG II measurement, plasma samples were stored at $-80^{\circ} \mathrm{C}$ for 1 to 3 months after the clinical investigation. After rapid thawing, they were extracted on Bondelut $\mathrm{PH}$ and the extract was purified on HPLC according to Nussberger et al. ${ }^{14}$ In the stored plasma samples of two patients ANG I was generated, due to inadequate conditions during transportation, despite the presence of the renin inhibitor. The corresponding ANG II concentrations indicated massive in vitro generation of ANG II and the values were therefore excluded from the analysis.

Statistical Analysis The results are reported as means \pm SEM. They were analyzed by nonparametric tests using the Kruskal-Wallis and Friedman tests for the analysis of variance, the Wilcoxon test for matched paired data and the Spearman rank coefficient for correlations. The level of significance was $P<.05$.

\section{RESULTS}

Influence of Captopril on Blood Pressure and ReninAngiotensin System According to the protocol, the 12 patients selected had a marked fall in mean blood pressure between 60 and $90 \mathrm{~min}$ after captopril intake: $15.3 \pm 1.5 \mathrm{~mm} \mathrm{Hg},(P<.001)$. Table 2 shows the results of the captopril test for each subgroup of 6 patients and also compares their results with the captopril test performed in 7 patients $24 \mathrm{~h}$ after the renin inhibitor infusion. PRA increased from $3.8 \pm 1.4$ to $20.6 \pm 9.6$ $\mathrm{ng} / \mathrm{mL} / \mathrm{h}(P<.001)$ after captopril and AR (active renin) rose by $215 \% \pm 90$. AR after captopril was correlated to the initial AR levels $(r=0.69, P<.01)$ and the increases in PRA and AR were closely correlated $(r=$ $0.96, P<.001)$. Plasma aldosterone was reduced by $52 \%$ from $178 \pm 25$ to $84 \pm 8 \mathrm{pg} / \mathrm{mL}(P<.01) 90 \mathrm{~min}$ after the administration of captopril.

Influence of CGP 38 560A on Blood Pressure (Figure 1) The dose of $0.125 \mathrm{mg} / \mathrm{kg}$ of CGP $38560 \mathrm{~A}$ induced a rapid fall in MABP. The maximum decrease occurred between 20 and $30 \mathrm{~min}$ after administration (5.7 \pm $2.2 \mathrm{~mm} \mathrm{Hg}, P<.05)$. MABP was back to baseline

TABLE 2. EFFECTS OF CAPTOPRIL ON BLOOD PRESSURE AND PLASMA RENIN

\begin{tabular}{|c|c|c|c|c|c|c|c|c|c|}
\hline \multirow{3}{*}{$\begin{array}{l}\text { Time } \\
(\min )\end{array}$} & \multicolumn{6}{|c|}{ 1st Captopril Test } & & & \\
\hline & \multirow{2}{*}{\multicolumn{3}{|c|}{$\begin{array}{c}\text { Patients infused with } \\
0.125 \mathrm{mg} / \mathrm{kg} \text { CGP } 38560 \mathrm{~A} \\
\mathrm{n}=6\end{array}$}} & \multirow{2}{*}{\multicolumn{3}{|c|}{$\begin{array}{c}\text { Patients infused with } \\
0.250 \mathrm{mg} / \mathrm{kg} \mathrm{CGP} 38560 \mathrm{~A} \\
\mathrm{n}=6\end{array}$}} & \multicolumn{3}{|c|}{ 2nd Captopril Test } \\
\hline & & & & & & & & $\mathrm{n}=7^{*}$ & \\
\hline \multirow{3}{*}{0} & MABP & PRA & RA & MABP & PRA & AR & MABP & PRA & AR \\
\hline & 125.8 & 5.2 & 99 & 120.8 & 2.5 & 40 & 115.2 & 3.7 & 65 \\
\hline & \pm 5.6 & $(0.6-18.1)$ & $(19-418)$ & \pm 6.0 & $(0.3-4.3)$ & $(14-80)$ & \pm 3.1 & $(0.2-9.9)$ & $(21-114)$ \\
\hline \multirow[t]{2}{*}{10} & 126.0 & & & 120.2 & & & 111.0 & & \\
\hline & \pm 6.4 & & & \pm 6.1 & & & \pm 3.9 & & \\
\hline \multirow[t]{2}{*}{20} & $119.6 \dagger$ & & & $115.2 \dagger$ & & & $105.4 \ddagger$ & & \\
\hline & \pm 4.6 & & & \pm 6.3 & & & \pm 4.0 & & \\
\hline \multirow[t]{2}{*}{30} & $115.4 \dagger$ & & & $113.5 \dagger$ & & & $102.0 \ddagger$ & & \\
\hline & \pm 4.7 & & & \pm 6.0 & & & \pm 2.9 & & \\
\hline \multirow[t]{2}{*}{45} & $112.5 \dagger$ & & & $108.7 \dagger$ & & & $100.6 \ddagger$ & & \\
\hline & \pm 4.6 & & & \pm 7.3 & & & \pm 2.4 & & \\
\hline \multirow[t]{2}{*}{60} & $110.4 \dagger$ & & & $109.4 \dagger$ & & & $98.1 \ddagger$ & & \\
\hline & \pm 4.2 & & & \pm 7.7 & & & \pm 2.5 & & \\
\hline \multirow[t]{2}{*}{90} & $109.1 \dagger$ & 36.2 & 533 & $106.8 \dagger$ & 5.0 & 65 & 99.9ł & 20.1 & 295 \\
\hline & \pm 4.3 & $(0.7-109)$ & $(23-2240)$ & \pm 7.2 & $(0.5-11.5)$ & $(20-103)$ & \pm 2.4 & $(0.3-77.5)$ & $(17-915)$ \\
\hline
\end{tabular}

${ }^{*}$ The 2 nd captopril test was performed in 4 patients infused with $0.125 \mathrm{mg} / \mathrm{kg}$ and 3 patients infused with $0.250 \mathrm{mg} / \mathrm{kg}$ CGP $38560 \mathrm{~A}$. $\dagger \mathrm{P}<.05, \ddagger \mathrm{P}<.01$. 


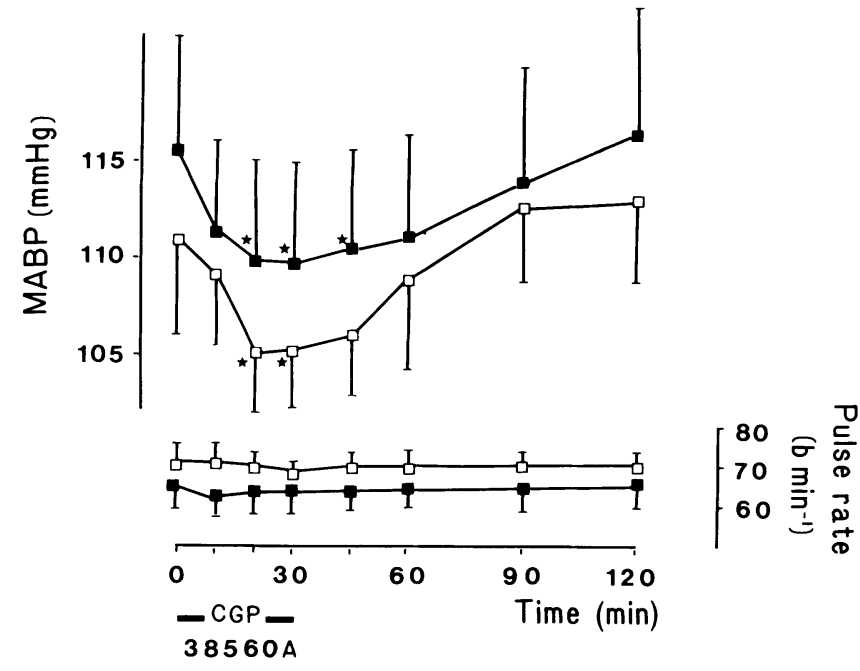

FIGURE 1. Effects of CGP $28560 A$ on mean arterial blood pressure and pulse rate according to the dose. Empty squares $(0.125 \mathrm{mg} / \mathrm{kg}, n=6)$, full squares $(0.250 \mathrm{mg} / \mathrm{kg}, n=6),{ }^{*} P<.05$.

$30 \mathrm{~min}$ after the end of the renin inhibitor infusion. A similar fall in MABP was observed $(6.0 \pm 1.8 \mathrm{~mm} \mathrm{Hg}$, $P<.05)$ with the higher dose $(0.250 \mathrm{mg} / \mathrm{kg})$. The fall remained significant until $15 \mathrm{~min}$ after the end of the infusion. The changes in systolic and diastolic blood pressure were parallel. Pulse rate remained unchanged with both doses. The maximum fall in MABP was significantly correlated to the initial PRA $(\mathrm{r}=0.61, P<.05)$.

Influence of CGP 38 560A on the Renin Angiotensin Aldosterone System (Table 3) PRA and AR were identical before captopril and CGP 38 560A. With both doses of the renin inhibitor, PRA fell below the detection limit in all patients between 10 and 45 min after starting the infusion. With the lowest dose PRA reappeared between 45 and $60 \mathrm{~min}$, whereas it remained undetectable with the $0.250 \mathrm{mg} / \mathrm{kg}$ dose up to $120 \mathrm{~min}$ after starting the infusion. PRA-TA returned towards baseline earlier. It was inhibited by $57 \%$ at $30 \mathrm{~min}$ after the end of the infusion of the lowest dose of the renin inhibitor, and by $62 \% 90 \mathrm{~min}$ after the end of the infusion of the highest dose, a time when PRA was still undetectable (Figure 2).

There were marked, stable, parallel falls in plasma ANG I and ANG II from 10 to 30 min after administration of the renin inhibitor. The fall in ANG I was greater with the higher dose $(74 \%$ after $0.125 \mathrm{mg} / \mathrm{kg} v 94 \%$ after $0.250 \mathrm{mg} / \mathrm{kg}, P<.01$ ). Exactly the same result was found for ANG II levels, which fell by $72 \%$ and $94 \%$, respectively. Both ANG I and ANG II returned to their initial levels at $60 \mathrm{~min}$ with $0.125 \mathrm{mg} / \mathrm{kg}$ doses of renin inhibitor, while the levels remained lowered up to 120 min following the higher dose (Figure 3). The maximum fall in MABP was significantly correlated to the maximum fall in plasma ANG I $(\mathrm{r}=0.77, \mathrm{n}=12, P<$
$.01)$, and plasma ANG I and ANG II were significantly correlated to one another $(\mathrm{r}=0.91, \mathrm{n}=79, P<.001)$.

Active renin (AR) rose significantly with the 2 doses, on average by $366 \%$, reaching a peak at $45 \mathrm{~min}$ ( $15 \mathrm{~min}$ after the end of the infusion) (Table 3). Then AR decreased progressively, remaining significantly above the pretreatment values at $120 \mathrm{~min}(P<.05)$, and declining to the pretreatment values at $24 \mathrm{~h}(75 \pm 21, P=\mathrm{NS})$. No dose dependency of the rise in AR could be demonstrated, but active renin levels after renin inhibitor were correlated to the initial active renin $(\mathrm{r}=0.82, P<.01)$.

Figure 4 compares the percentage changes in plasma ANG II, MABP and reciprocal active renin. It shows the parallelism of the time-course of events for these three variables.

Similar variations in plasma aldosterone levels were observed with both doses. On average, aldosterone decreased by $27 \%$ to attain a minimum at $45 \mathrm{~min}(103 \pm$ $10 v 142 \pm 17 \mathrm{pg} / \mathrm{mL}, P<.01)$, and then returned to its initial value.

Comparison Between CGP 38 560A and Captopril The fall in blood pressure induced by captopril was significantly correlated to that induced by the renin inhibitor $(\mathrm{r}=0.53, \mathrm{n}=12, P<.05)$. In percentage, as well as in absolute values, the fall in blood pressure was more marked 60 to 90 min after converting enzyme inhibition $(13.0 \pm 4.3 \%)$ than after $30 \mathrm{~min}$ of renin inhibition $(5.3 \pm 3.3 \%, P<.001)$. In addition, the fall in MABP became significant $(5.8 \pm 1.1 \mathrm{~mm} \mathrm{Hg}, \mathrm{n}=12, P<.05)$ $20 \mathrm{~min}$ after captopril ingestion, and at $30 \mathrm{~min}$ it was already greater $(8.8 \pm 2.0 \mathrm{~mm} \mathrm{Hg}, \mathrm{n}=12)$ than the fall in blood pressure induced by the renin inhibitor at $30 \mathrm{~min}(5.8 \pm 1.4 \mathrm{~mm} \mathrm{Hg})$. The MABP was higher be-

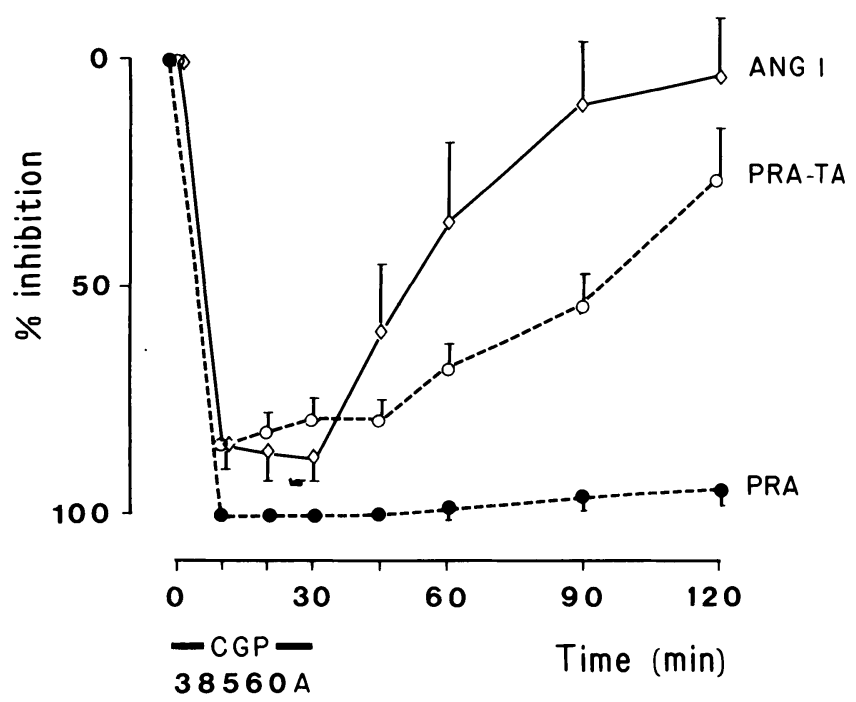

FIGURE 2. Percentage falls in plasma angiotensin I (ANG I) and plasma renin activity measured by the conventional $P R A$ or by the ANG I trapping assay (PRA-TA). 

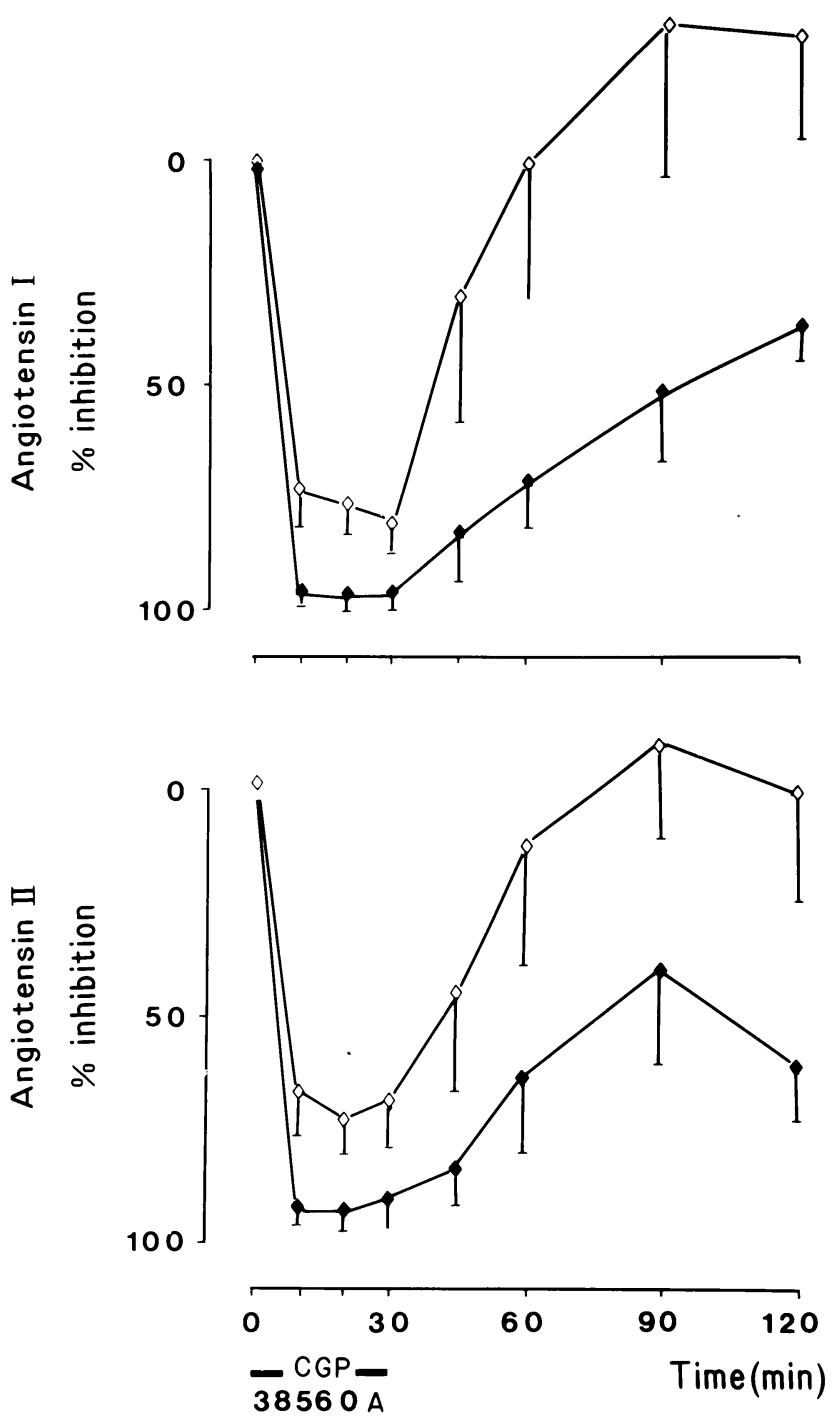

FIGURE 3. Percentage falls in plasma angiotensins I (ANG I, $n=12$ ) and II (ANG II, $n=10$ ) according to the dose of CGP 38 $560 \mathrm{~A}$ with empty $(0.125 \mathrm{mg} / \mathrm{kg})$ or full $(0.250 \mathrm{mg} / \mathrm{kg})$ diamondshaped points.

fore captopril than before CGP 560A infusion (123 \pm $4.0 v 113.2 \pm 3.5, \mathrm{n}=12, P<.01)$, probably because the captopril test was performed at an earlier stage of the patients' hospitalization. However, the 7 patients who had a second captopril test $24 \mathrm{~h}$ after the renin inhibitor infusion had pre-captopril blood pressure values identical to those recorded before the renin inhibitor infusion (Table 2). The decrease in MABP observed after this second administration of captopril was still significantly greater $(15.3 \pm 3 \mathrm{~mm} \mathrm{Hg})$ than the fall in MABP induced by the infusion of the renin inhibitor $(6.4 \pm$ $1.2 \mathrm{~mm} \mathrm{Hg}, \mathrm{n}=7$ ). Active renin before captopril was very significantly correlated with active renin before CGP $38560 \mathrm{~A}(\mathrm{r}=0.92, \mathrm{n}=12, P<.001)$, and the rise in active renin $90 \mathrm{~min}$ after captopril ingestion was also correlated to the maximum rise in active renin induced by the renin inhibitor infusion $(\mathrm{r}=0.99, \mathrm{n}=12, P<$ $.001)$.

\section{DISCUSSION}

The results of this initial investigation of the renin inhibitor CGP $38560 \mathrm{~A}$ in hypertensive patients demonstrate that infusion of a renin inhibitor lowers blood pressure in hypertensive patients who respond favorably to captopril. This confirms both the medical concept and the validity of the methods used for the design and the selection of CGP 38 560A. ${ }^{5}$ The fall in blood pressure occurs without an acceleration in heart rate at a dose which is ten times lower than that of $\mathrm{H} 142$, the first renin inhibitor which was injected in sodium-depleted healthy volunteers. ${ }^{15}$ The rapid fall in blood pressure between 0 and $10 \mathrm{~min}$ and its return to initial values are strictly in parallel with the fall in, and the reappearance of, circulating ANG I and ANG II. Because these patients were selected on the basis of a fall in blood pressure after captopril ingestion, they had a renin-dependent form of hypertension, which explains why the fall in blood pressure is correlated to the fall in plasma ANG I and ANG II. The dose-dependency easily detected in the plasma ANG I and ANG II measurements was not found in the blood pressure. This shows that the biochemical phenomenon-renin inhibition-is optimally investigated by the measurement of these peptides, whereas the clinical consequence of renin inhibition, the fall in blood pressure, is only partially dependent on renin inhibition. It depends on the contribution of the renin-angiotensin system to the maintenance of blood pressure in each patient, which makes it difficult to build dose-response curves on blood pressure with a small number of patients.

The rise and then the fall in the AR in the plasma during renin inhibition occurred slightly after the changes in plasma ANG I and ANG II and the subsequent changes in blood pressure. Whereas dose-dependent suppression of both ANG I and ANG II reached its nadir during CGP 38 560A infusion, the increase in AR in the plasma, reached its zenith 15 min later, which reflects the longer plasma half-life of renin compared with angiotensins.

The rise in AR was not dose-dependent. The magnitude of the reactive renin release is characteristic for each individual, as suggested by the very significant correlation between the changes in AR after captopril and CGP $38560 \mathrm{~A}$. As the blood pressure falls, these changes in AR were extremely variable from one patient to the other, and a possible influence of the renin inhibitor dose was blunted by other predominant factors such as the initial rate of renin release and renin synthesis, processing and storage in the juxtaglomerular cells.

This study raises two challenging questions: why do PRA and the decrease in blood pressure dissociate after 


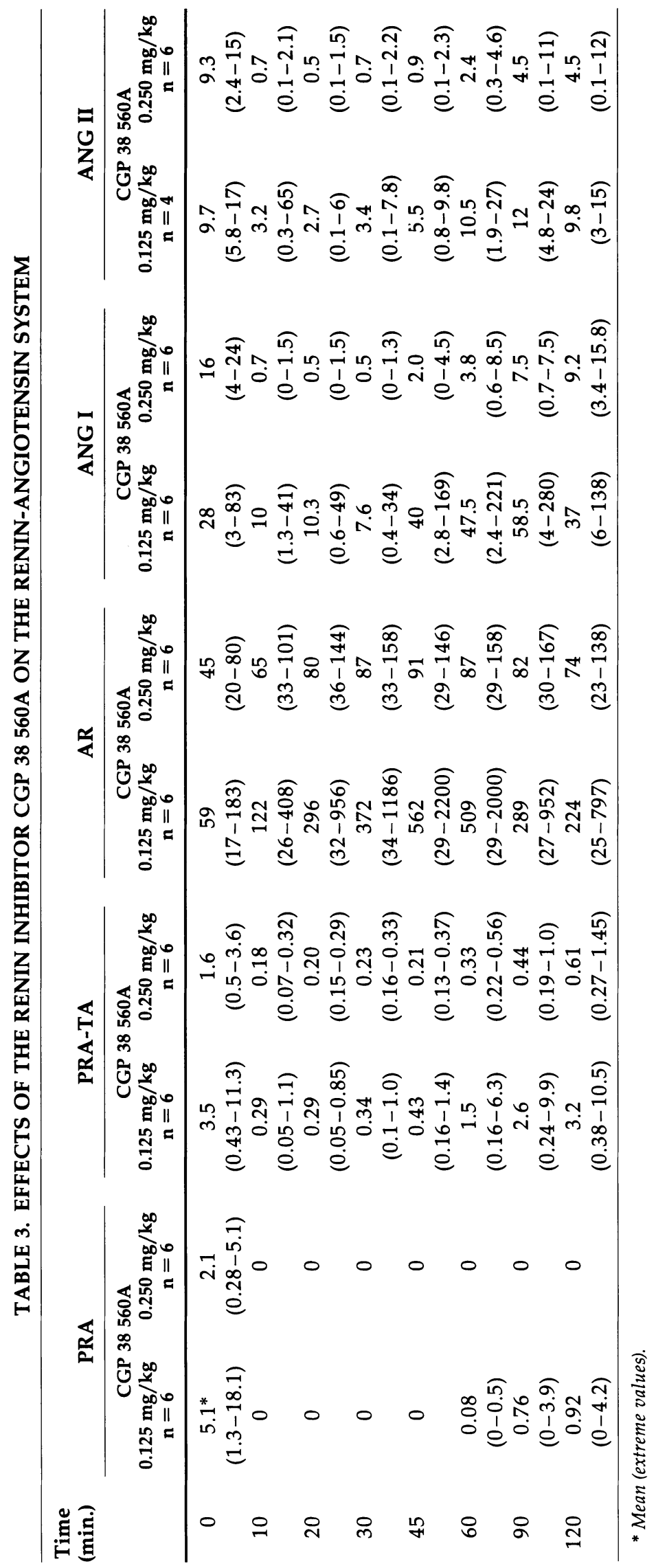




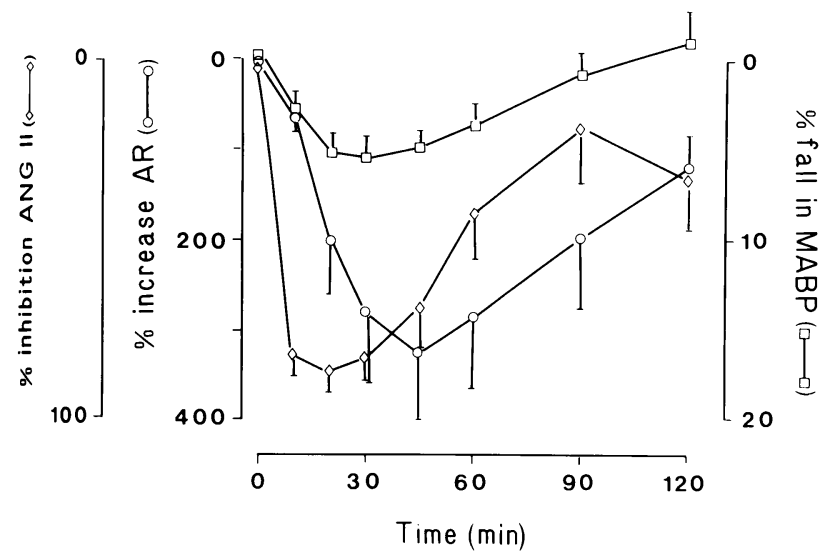

FIGURE 4. Effects of CGP $38560 A$ on mean arterial blood pressure (MABP, square), angiotensin II (ANG II, diamondshaped) and active renin $(A R$, circle). The results are expressed in percent of the control value.

renin inhibition, and why is captopril more hypotensive than CGP 38 560A? Apparently, this clinical investigation of a renin inhibitor in hypertensive patients confirms the observation made in animals ${ }^{3,4}$ and, in a preliminary report, in hypertensive patients injected with the renin inhibitor A64662. ${ }^{16}$ The in vitro inhibition of plasma renin activity is dissociated from the changes in blood pressure after administration of a renin inhibitor and blood pressure returns towards its initial value despite a much more prolonged in vitro suppression of plasma renin activity. Another kind of dissociation was also previously observed, between plasma ANG II levels and PRA in healthy volunteers on a normal sodium intake. A long-lasting suppression of PRA measured by a conventional method was present for $150 \mathrm{~min}$ after the end of this renin inhibitor infusion, despite a normalization of plasma ANG II. ${ }^{6}$ In another investigation, the same doses of this renin inhibitor were infused in normal volunteers after a mild sodium depletion induced by furosemide $40 \mathrm{mg}$. $^{7}$ Plasma ANG II was measured by the same method as in the previous experiment, ${ }^{14}$ but PRA was investigated by the ANG I trapping assay. ${ }^{7}$ The inhibition of PRA-TA was much shorter than the inhibition of PRA observed in the volunteers not subjected to sodium restriction. However, it was still present $90 \mathrm{~min}$ after the end of the renin-inhibitor infusion, whereas ANG II levels returned to their initial values at $30 \mathrm{~min}$.

In the present investigation, we demonstrate that the two PRA methods used in parallel to investigate in vitro ANG I generation provide results different from the in vivo measurements. Plasma ANG I, the immediate product of the in vivo renin reaction, plasma ANG II, the active peptide, and blood pressure returned to the vicinity of their initial values before PRA measurements. The conventional measurement of PRA grossly overesti- mated the in vivo duration of action of the renin inhibitor, whereas the PRA-TA came much closer to plasma ANG values, although it still differed. We conclude that the conventional method of PRA measurement is not appropriate for quantifying the in vivo renin inhibition. This conclusion is not exclusive to CGP $38560 \mathrm{~A}$ and may also be true for other renin inhibitors synthesized according to a similar approach. ${ }^{1,16,17}$

The second challenging observation is the small fall in blood pressure under CGP $38560 \mathrm{~A}$ compared with that observed under captopril, despite a dramatic fall in plasma ANG I and plasma ANG II. Although the comparison of the oral administration of a converting enzyme inhibitor with the intravenous infusion of a renin inhibitor is difficult to make, and was not in fact the initial goal of this investigation, it is certainly an important observation. The fall in MABP during renin inhibition by CGP $38560 \mathrm{~A}$ was less than the fall induced by the single oral administration of $50 \mathrm{mg}$ captopril, a dose which is widely used to investigate the role of the renin angiotensin system in hypertensive patients. ${ }^{8}$ This difference was not dependent on the level of MABP before the test ${ }^{18}$ since it is also observed in the 7 patients who had a second captopril test, and who at this time had the same initial levels of MABP before converting enzyme inhibition as prior to renin inhibition. This observation contrasts with the results previously obtained in marmosets. The magnitude of the fall in blood pressure induced by a renin inhibitor (GGP 29287 ) was similar to the fall induced by a converting enzyme inhibitor (teprotide) ${ }^{19}$ which suggested that the two types of inhibition were equally effective on blood pressure.

The more pronounced effect of the ACE-inhibitor, compared with the renin inhibitor, could be due to a biochemical effect such as bradykinin accumulation, in addition to exclusive ANG II suppression. Such a bradykinin accumulation might add its own antihypertensive effect, directly or through prostaglandin synthesis, on top of the hypotension induced by ANG II suppression. ${ }^{20}$ However, recent animal experiments have challenged this hypothesis. ${ }^{21}$

Another explanation, within the renin angiotensin system, would be a difference in the degree of the blockade achieved by the two different inhibitors of the renin-angiotensin system at the selected doses. According to our observations on the limitations of in vitro ANG I generation in the presence of a renin inhibitor, the in vitro potency of CGP $38560 \mathrm{~A}$ may have been overestimated, which might explain why the full efficacy of renin inhibition could not be obtained with this compound, despite circulating levels of CGP $38560 \mathrm{~A}$ theoretically more than 1000 times higher than the calculated $K_{1}(0.4 \mathrm{nmol}) .^{5,22}$ In the 10 patients evaluated, ANG II levels fell to values below $1 \mathrm{fmol} / \mathrm{mL}$ during infusion of CGP $38560 \mathrm{~A}$ in only 6 subjects, while in the other 4 the ANG II levels remained at peak renin inhibi- 
tion between 1.1 and $6.0 \mathrm{fmol} / \mathrm{mL}$, despite an important decrease of $65-93 \%$ from pre-infusion values. These results are at variance with the low unmeasurable levels which were observed in all healthy volunteers tested previously with $25 \mathrm{mg}$ intravenous captopril. ${ }^{23}$ It is therefore possible that plasma ANG II was less suppressed after the infusion of the renin inhibitor at the doses selected than after ACE inhibition. A definite conclusion is not possible since plasma ANG II was not measured during the initial captopril test, which was only used to screen renin-dependent hypertension, and moreover, the discriminatory power of plasma ANG II measurements at these low levels may still need to be improved.

Conceivably, a major fall in ANG I and ANG II levels in plasma, although necessary, may not be sufficient to adequately explain the magnitude of the fall in blood pressure due to a blockade of the renin-angiotensin system. The inhibition of the angiotensin I converting enzyme, which is mostly immobilized on the endothelial cells and produces ANG II near to its receptors on the vascular smooth muscle cells, might have more effect on the blood pressure than the inhibition of the renin circulating in the plasma compartment. To be optimally effective, renin inhibition might require a more complete suppression of ANG I generation at additional plasma sites, such as the interstitial space, where both renin and angiotensinogen are present. ${ }^{24,25}$ Therefore, our results should not be extrapolated to renin inhibition in general and are certainly dependent on the characteristics of this class of renin inhibitor, represented by CGP $38560 \mathrm{~A}$. CGP $38560 \mathrm{~A}$ is strongly bound to plasma proteins and its volume of distribution may not allow for a sufficient diffusion to the in vivo production sites of ANG I in the interstitial space. Other renin inhibitors, more potent, less protein-bound and less rapidly metabolized are needed in order to know if an additional fall in blood pressure might occur beyond that induced by the fall in plasma angiotensins.

\section{ACKNOWLEDGEMENT}

The help of Mrs. Danièle Ménard in performing the infusions and of Mrs. Nicole Schaeffer in typing the manuscript is gratefully acknowledged. The technical assistance of Miss Catherine Amstutz and Mrs. Christiane Dollin is acknowledged with thanks.

\section{REFERENCES}

1. Greenlee WJ: Renin inhibitors. Pharmaceutical Research 1987;4:364-374.

2. Case DB, Wallace JM, Keim HJ, et al: Estimating renin participation in hypertension: superiority of converting enzyme inhibitor over saralasin. Am J Med 1976;61:790-796.

3. Blaine EJ, Schorn TW and Boger J.: Statine containing renin inhibitor. Dissociation of blood pressure lowering and renin inhibition in the sodium-deficient dog. Hypertension 1984;6(suppl I):I111 -I118.

4. Kleinert HD, Martin D, Chekal M, et al: Cardiovascular actions of the primate-selective renin inhibitor, A 62198. J Pharmacol Exp Therap 1988;246:975-979.

5. Bühlmayer P, Caselli A, Fuhrer W, et al: Synthesis and biological activity of some transition-state inhibitors of human renin. J Med Chem 1988;31:1839-1846.

6. De Gasparo M, Cumin F, Nussberger J, et al: Pharmacological investigations of a new renin inhibitor in normal sodium-unrestricted volunteers. Br J Clin Pharmacol 1989;27:587-596.

7. Nussberger J, Delabays A, De Gasparo M, et al: Hemodynamic and biochemical consequences of renin inhibition by infusion of CGP $38560 \mathrm{~A}$ in normal volunteers. Hypertension 1989;13:948-953.

8. Müller FB, Sealey JE, Case DB, et al: The captopril test for identifying renovascular disease in hypertensive patients. Am J Med 1986;80:633-644.

9. Sealey JE, Gerten-Barnes J, Laragh JH: The renin system: variations in man measured by radioimmunoassay or bioassay. Kidney Int 1972;1:240-253.

10. Poulsen $K$, Jorgensen J: An easy radioimmunological microassay of renin activity, concentration and substrate in human and animal plasma and tissues based on angiotensin I trapping by antibody. J Clin Endocrinol Metab 1974;39:816-825.

11. Ménard J, Guyene TT, Corvol P, et al: Direct immunometric assay of active renin in human plasma. J Hypertension 1985;3(Suppl.3):275-278.

12. Pham Huu Trung MT, Corvol P: A direct determination of plasma aldosterone. Steroids 1974;24:587-598.

13. Nussberger J, Brunner DB, Waeber B, Brunner HR: In vitro renin inhibition to prevent generation of angiotensins during determination of angiotensin I and II. Life Sci 1988;42:1683-1688.

14. Nussberger J, Brunner DB, Waeber B, Brunner HR: True versus immunoreactive angiotensin II in human plasma. Hypertension 1985;7(suppl I):11-17.

15. Webb DJ, Manhem P, Ball SG, et al: A study of the renin inhibitor H142 in man. J Hypertension 1985;3:653-658.

16. Bursztyn M, Gavras I, Boger R, et al: Dissociation between plasma renin inhibition and blood pressure response to a renin inhibitor in hypertensive patients (abstr.). 42nd Annual Fall Conference, Council for High Blood Pressure Research, Sept. 28-Oct. 1, 1988, San Francisco.

17. Delabays A, Nussberger J, Porchet $M$, et al: Hemodynamic and humoral effects of the new renin inhibitor enalkiren in normal humans. Hypertension 1989; 13:941-947.

18. Gill JS, Beevers DG, Zezulka AV, Davies P: Relation between initial blood pressure and its fall with treatment. Lancet 1985;i:567-569.

19. Wood JM, Gulati N, Forgiarini P, et al: Effects of a specific and long-acting renin inhibitor on blood pressure in the marmoset. Hypertension 1988;7:797-803.

20. Gavras I, Gavras H: Role of bradykinin in hypertension and antihypertensive effect of angiotensin converting enzyme inhibition. Am J Med Sci 1988;295:305-307. 
21. Waeber B, Aubert JF, Flückiger JP, et al: Role of endogenous bradykinin in blood pressure control of conscious rats. Kidney Int. 1988;34(suppl 26):S63-S68.

22. Wood JM, Criscione L, De Gasparo M, et al: CGP 38 560A: orally-active, low molecular weight renin inhibitor with high potency and specificity. J Cardiovasc Pharmacol (in press).

23. Nussberger J, Waeber G, Waeber B, et al: Plasma angio- tensin-(1-8)octapeptide measurement to assess acute angiotensin converting enzyme inhibition with captopril administered parenterally to normal subjects. J Cardiovasc Pharmacol 1988;11:716-721.

24. Lever AF, Peart WS: Renin and angiotensin-like activity in renal lymph. J Physiol 1962;160:548-563.

25. Campbell DJ: The site of angiotensin production. J Hypertens 1985;3:199-207. 